\title{
Explanatory Definitions of the Technology Push Success Factors
}

\author{
Jari Sarja'
}

\begin{abstract}
The main task for most development-intensive organizations is to create, develop and commercialize new products and services. Because development processes are risky and failure rates are high, especially in the case of technology pushed projects, unambiguous success factors are valuable knowledge for the management of development-intensive firms. New product development and innovation literature has presented many success factors for developed products, but, unfortunately, many of them are nebulous in nature. The aim of this paper is to clarify what elements comprise the exact factors. After an extensive review and screening of the technology push success factor related literature, a total of 13 success factors were rationalized and transcribed according the previous literature. As a result, three separate keynotes were recognized, and the survey instrument framework was proposed. The practical relevance of this study is to help firm management to recognize the real actions needed to reduce product development risks and also to help scholars to focus on key issues when studying the key factors of breakthrough development cases.
\end{abstract}

Keywords: technology push; success factor; new product development; survey instrument

'Department of Information Processing Science, University of Oulu, Pentti Kaiteran katu I, FI-90570, Oulu, Finland.

Phone: +358 40672 1024. e-mail: jari.sarja@oulu.fi

ISSN: 07 I8-2724. (http://www.jotmi.org)

Journal of Technology Management \& Innovation @ Universidad Alberto Hurtado, Facultad de Economía y Negocios. 


\section{Introduction}

The main task for most NPD intensive organizations is to create, develop and commercialize new products and services. However, this is a complex and difficult task. NPD being the backbone of many industries, it is obvious that it is of considerable interest to multidisciplinary research. The quantity of NPD research during recent decades has been tremendous (e.g., Balachandra \& Friar, 1997; Ernst, 2002). This research has, almost without exception, been aimed to identify the success factors of new products. The impulse for the development of a new product comes either from customer needs (MP) or from internal or external research (TP).

According to the concept of MP, market demand is the main driver of innovation. The concept of TP suggests instead that the driver for innovation is internal or external research and that the target is to develop new technology for commercial purposes.

Even recent NPD literature does not set a clear arrangement in the TP-MP debate; it leaves some space for interpretation at the case level (Herstatt \& Lettl, 2004) and leaves a possibility to combine both of these strategies. Still, few successful firms in the market prefer the TP approach, either intentionally or accidentally. To give an example of companies in different scales that adhere to the TP approach, one can name Apple (Isaacson, 20II) and 37signals (Sarja, 20I2). Apple did not do market researched, and 37 signals defends their way of not listening to customers in the development phase. The TP strategy dominates radical innovation and MP dominates incremental innovation.

Innovation is generally defined as a new technology or combination of technologies that offer valuable benefits to the users. The difference between radical and incremental innovation is the state of novelty. Radical innovation involves the development of considerable new technologies or market ideas previously unknown or that require remarkable changes to what currently exists in the market. Incremental innovation is an extension of current products or existing processes (e.g., McDermott \& O'Connor, 2002).
Even though the definition of radical innovation varies in the literature (e.g., Green et al., 1995; McDermott \& O'Connor, 2002), one valid and measurable definition by Green et al. (1995) incorporates four dimensions: technological uncertainty, technical inexperience, business inexperience and technology cost. Many researchers have also added change dimensions: the change of customer behavior (e.g., Samli \& Weber, 2000) and the change of the existing market (e.g., McDermott \& O'Connor, 2002). If these characteristics are collated, it is obvious that the development of radical projects has higher risks but also higher profit expectations (e.g., Christensen, 1997; Samli \& Weber, 2000).

Because development processes are risky and failure rates are high, especially in the case of TP projects, unambiguous success factors are valuable knowledge for the management of development-intensive firms.

Sarja (2015) studied two meta-analyses for finding the success factors of TP projects in an ICT context. However, the author concluded that the TP success factors - according to the current research - are industry independent. We found that the 13 success factors (table I) are not very exact; rather, they are descriptive vague topics. We see this issue as somewhat problematic; the success factors are too wide, or they may have many different meanings. Balachandra and Friar (1997) concluded the same confusion of NPD research previously.

The research problem of this paper is to clarify what elements comprise the exact factors. The research subject is 13 success factors collected from the meta-analyses by Samli and Weber (2000) and Bishop and Magleby (2004). For rationalizing and transcribing the success factors, we searched related concepts from previous literature, including research papers and established books. In this paper, we introduce the proposed reasoning of the success factors. In addition, the survey instrument framework for TP case studies is proposed.

At first, the thematized success factors (Sarja, 20I5) are presented and transcribed and the framework of the survey instrument for case testing is introduced. Then, the findings are discussed and summarized in the last chapter. 


\begin{tabular}{|l|l|l|l|l|l|l|l|}
\hline Market related & MA' & $\begin{array}{l}\text { Product } \\
\text { related }\end{array}$ & MA & $\begin{array}{l}\text { Management } \\
\text { related }\end{array}$ & MA & $\begin{array}{l}\text { Organisa- } \\
\text { tion related }\end{array}$ & MA \\
\hline Focus on customer needs & BM $^{2}$ & $\begin{array}{l}\text { TP for difficult } \\
\text { adopted }\end{array}$ & SW & $\begin{array}{l}\text { Management } \\
\text { support }\end{array}$ & BM & Networking & BM \\
\hline MP methods used & BM & Life cycle & SW & Degree of funding & SW & $\begin{array}{l}\text { Project team } \\
\text { skills }\end{array}$ & BM \\
\hline Market development & BM & $\begin{array}{l}\text { Fill an unrec- } \\
\text { ognised need }\end{array}$ & SW & & & & \\
\hline Alternative study & BM & $\begin{array}{l}\text { Technological } \\
\text { advantages }\end{array}$ & SW & & & & \\
\hline Adoption time/ technophobia & SW 3 & & BM & & & & \\
\hline $\begin{array}{l}\text { ' meta-analyses } \\
{ }^{2} \text { Author: Bishop \& Magleby (2004) } \\
{ }^{2} \text { Author: Samli \& Weber (2000) }\end{array}$ \\
\hline
\end{tabular}

Table I.TP success factors (Sarja, 2015)

\section{Specification of the TP success factors}

The NPD and innovation literature have presented many success factors for developed products. Parts of these factors are comprehensible, but, unfortunately, many of them have conspicuous characteristics; they are nebulous in nature. Many times, they can be explained many ways. Balachandra and Friar (1997) concluded this previously, and, as an example, they underlined that the terms "emphasize marketing" and "support of top management" may take many different forms. The authors explain the factors that are considered so self-evident in many cases that no clear definitions are given, even though they may have different meanings. The same phenomenon applies to the previous study of Sarja (2015). As the author concludes, "The current literature does not provide exact key factors but instead, rather descriptive vague topics."

For rationalizing the success factors, we have divided them into smaller, precise pieces and proposed a reasoning of the factors.

\section{Market related success factors}

\section{MP methods used}

We see that MP thought is not a method but rather is an innovation driver approach (e.g., Herstatt \& Lettl, 2004; Sarja 2015), and this key factor covers somewhat the next three market related success factors: a focus on customer needs, market development and alternative study. In addition, following the MP based generic development process introduced by Ulrich and Eppinger (2008), the MP approach will be taken into consideration. The general level description of the generic development process is illustrated in figure $\mathrm{I}$.

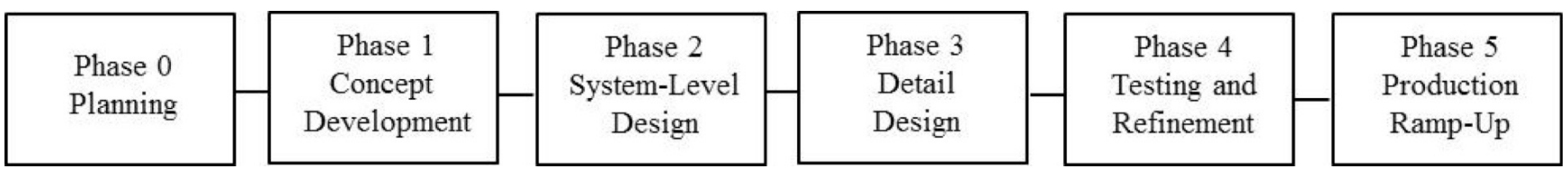

Figure I. Generic development process (source: Ulrich \& Eppinger, 2008)

ISSN: 07 I8-2724. (http://www.jotmi.org) 
The generic development process describes the market-pull situation. The authors separate the TP and MP situations, explaining that, in the TP case, a firm begins with a new technology and tries to find an appropriate market; whereas, in the MP case, a firm begins development with a market opportunity and tries to satisfy market needs using whatever technologies are available. This separation is done by adding technology-market matching to the first phase (planning) of the (market pull) process.
In summary, it can be concluded that the development process itself should be the same regardless of the innovation driver (TP or MP). This premise is supported by numerous studies with different NPD perspectives, for example, marketing-R\&D co-operations or TP-MP integrated models (e.g., Freeman, 1982; Zmud, 1984; Munro \& Noori, 1988; Souder, 1989; Herstatt \& Lettl, 2009). The framework of this thought is presented in figure 2 .

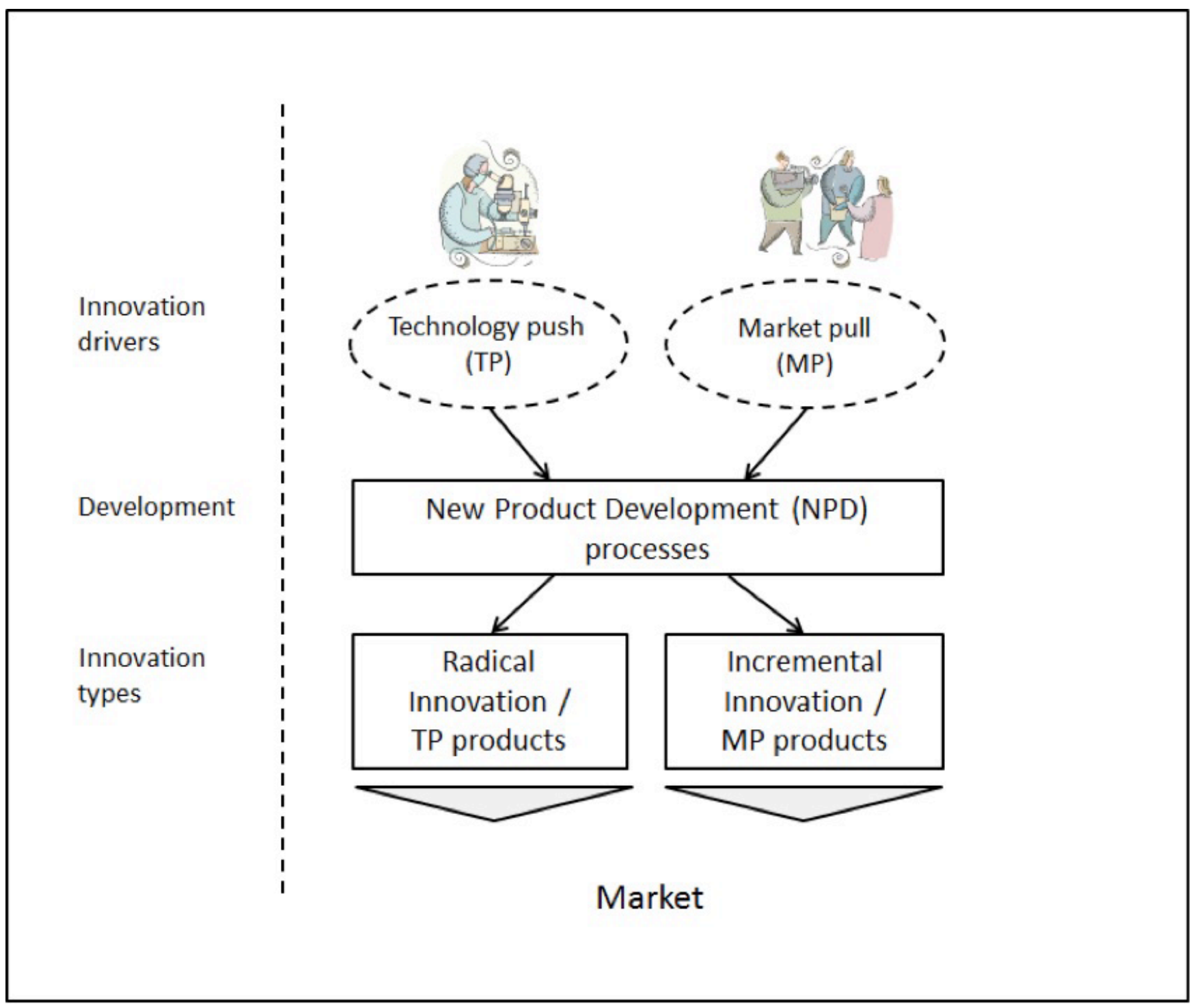

Figure 2.The framework of NPD success factor research (Sarja, 20I5) 


\section{Focus on customer needs}

Customer needs means basically that the customer solves some problem by purchasing a product (a good or service). Most literature about NPD, also TP-focused, stresses that customer needs must be identified at the beginning of the development process. For example, Ulrich and Eppinger (2008) examine preparatory customer related studies, including customer needs collection for the two first phases ( 0 =planning, I=concept development), in their generic development process. After articulating market opportunities and defining market segments in the planning phase, the needs of segmented customers (e.g., Kotler \& Armstrong, 1987, pp. 203-224) in a target market should be identified in the concept development phase. The output of identifying customer needs is a constructed list of customer need statements, organized in hierarchical order with importance weightings. The five-step process for identifying customer needs is:

I. Gather raw data from customers

2. Interpret the raw data in terms of customer needs

3. Organize the needs into a hierarchy of primary, secondary and (if necessary) tertiary needs

4. Establish the relative importance of the needs

5. Reflect on the results and the process

\section{Market development}

The term market development has many statements. Thinking about the found success factor of a TP product, it is reasonable to adopt the commonly used Ansoff model (Figure 3). The Ansoff model describes firm growth strategy opportunities. It contains four growth options that are used based on product and market maturities.

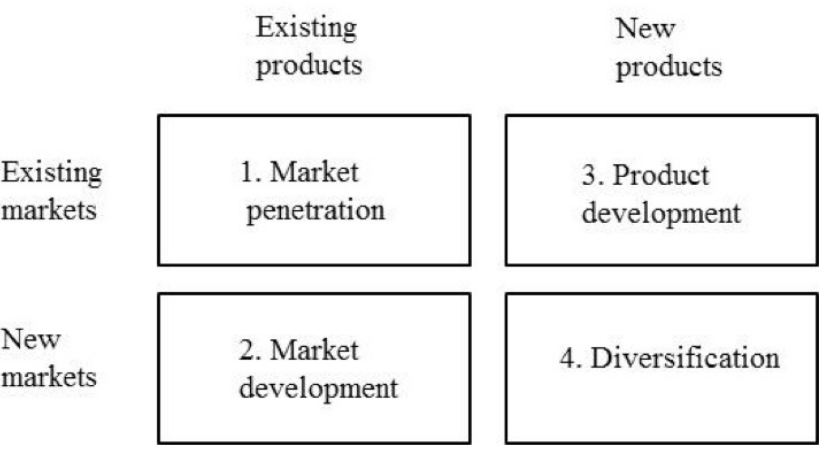

Figure 3.The Ansoff model (Ansoff, 1957)
In the model, market development means a firm's attempt to identify and develop new markets for current products. However, it does not apply to the new product context. Therefore, when we use the concept of market development in this paper, we actually mean the concepts of product development (new products for existing markets) and diversification (new products for new markets).

Bishop and Magleby (2004) state that the market must be developed, instructed or prepared simultaneously with the development of a product (see Sarja, 2015, chapter 3.1). We agree with this view in terms of the definition of a target market by a development firm.

\section{Alternative study}

Alternative study regards a kind of sub-process in the concept development phase of the development process that is similar to customer needs identification. Time-wise these two processes will be actualized simultaneously. Ulrich and Eppinger (2008) state that the alternative product concept must be generated and evaluated in the concept development phase.

There are numerous studies of competitor analysis in marketing literature (e.g., Chen, 1996; Peteraf \& Bergen, 2002; 2003). We would like to note a slight difference between the concepts of alternative analysis and competitor analysis. Competitor analysis is a marketing related term concerning products, whereas alternative study (or analysis) concerns only new products, processes and methods (in the market). Because there is not a significant number of studies about alternative analysis, we make an assumption that alternative studies can be done with the same method as competitor analyses.

A significant argument was found by Lewitt (1960). He stated that business should not be defined in terms of product types but in terms of customer needs to be served. This thought encourages management to study business and growth opportunities more broadly (Peteraf \& Bergen, 2003). An example of this aspect is the electric car. The other brands are not the only competitors; other economical vehicles and even public transportation are also competitors. 
With a similar thought, Chen (1996) defined the framework for competitor analyses. It was based on two dimensions: market commonality and resource similarity. The framework maps three kinds of competitors, indirect (substitutes), direct and potential, depending on the degree of dimensions. The framework of competitor analysis is illustrated in figure 4 .

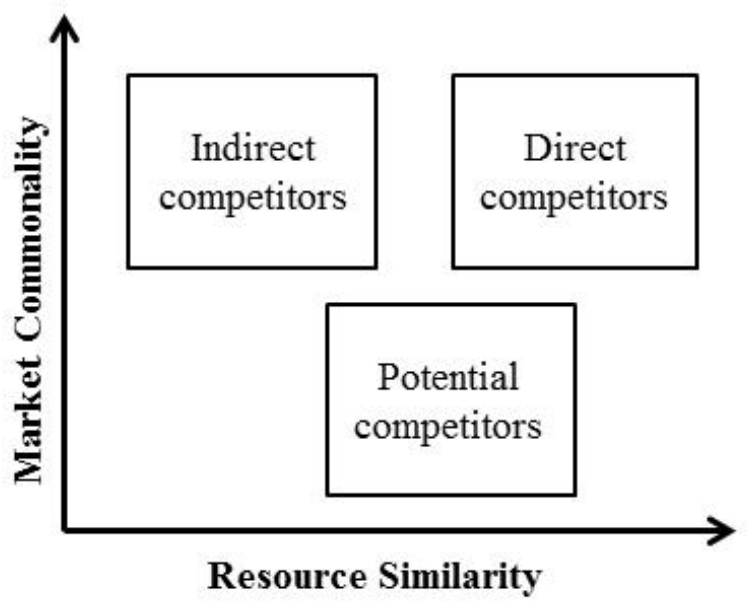

Figure 4. The framework of competitor analysis (based on Chen, 1996; Bergen \& Peteraf, 2002)

\section{Adoption time, technophobia}

Adoption time is the space of time when the consumer adopts new products or ideas. The more dramatic a new product is, the longer the adoption time (e.g. Samli \& Weber, 2000). There are many models to explain adoption (e.g., Mahajan \& Wind, 1986; Mahajan et al., 1990; Sultan et al., 1990, Narayanan, 1992). Most models are based on the Bass (1969) model (Narayanan, 1992).

There are many definitions for the noun technophobia, and the early definitions are from the PC era. Brosnan (1998) uses the most commonly cited definition of Jay (198I) in his landmark book about technophobia. Jay (198I) defines technophobia as the following:

I. A resistance to talking about computers or even thinking about computers

2. Fear or anxiety towards computers

3. Hostile or aggressive thoughts about computers
Briefly, Brosnan (1998, p. 33) states that the overall concept of technophobia is a combination of computer anxiety and a negative attitude. In this study, we deal with the given definitions, but we expand the cause of technophobia from computers to any technology based new product.

We see that these two concepts, adoption time and technophobia, have a clear linkage in the field of NPD research, particularly when speaking about technology pushed products. Many scholars and research communities are in step with us, for example when explaining that user acceptance has been a long-term issue in highly esteemed MIS research (Davis, 1989). Brosnan (1998, p. I7I) and the $\mathrm{HCl}$ community (Davis, 1989) emphasize a commercial motivation for continued user-friendliness in hardware and software due to an attempt to appeal to technophobes.

Different technology acceptance models support this thought; users must feel that an application is useful (perceived usefulness) and easy to use (perceived ease of use). The roots of acceptance models are multidisciplinary, from sociology and psychology to information system research (IS) (see e.g., Venkatesh et al., 2003). In NPD research, the most known and highly cited technology acceptance model is TAM (Davis, 1989) and its extensions, TAM 2 (Venkatesh \& Davis, 2000), TAM 3 (Venkatesh \& Bala, 2008) and the unified theory of acceptance and use of technology (UTAUT) (Venkatesh et al., 2003). Technology acceptance models explain why users adopt or do not adopt new applications and give tools to promote positive adoption. The weakness of the models is that they do not take into account the time of adoption.

\section{Product related success factors}

\section{TP for difficult adopted}

TP driven products typically take longer to be adopted by the majority of customers (see the categories of adopters by Rogers, 1962). The adoption time from the customer's point of view and the natural resistance of users to new solutions is discussed above. This factor is the adoption time domain from the developers' perspective. The longer the adoption time from a firm's point of view, the longer the run commitment to a project, especially in terms of resources. This is one reason, which makes TP projects risky. If risk is controlled and a product succeeds, the expected life cycle is also longer.

\section{Life cycle}

Firms develop new products to get long-term profits (Griffin \& Hauser, 1996). A good example of the expected longer life cycle of successful technology push (also called as breakthrough) products is a study of Samli and Weber

ISSN: 07I 8-2724. (http://www.jotmi.org) 
(2000), where they examined successful breakthrough developers, in total, I 30 firms with 143 products, which had been in the market for over a decade.

Product life cycle means total product existence from raw material sourcing to manufacturing steps, usage and, finally, to discarding or recycling (e.g., Tseng \& Chen, 2004). For the firm's perspective, we widen this concept by including also the development phase. The basic idea behind the life cycle factor, from an idea until the end of a product's life, is economic planning. Samli and Weber (2000) see life cycle reasoning as a financial and human resource issue.

\section{Fill an unrecognized need}

The importance of focusing on customer needs in the development phase is discussed above. In the ideal world, a radical or breakthrough product fills a need customers did not consider. However, proceeding totally with an internal technology push is a lottery game. Samli and Weber (2000) emphasize that a new product must fulfil at least a somewhat recognized need. Calantone and $\mathrm{Li}$ (1998) are in step, stating that if a company has no knowledge of the market, it is not likely to be successful.

\section{Technological advantages}

Technological advantage is a multilevel concept. Depending on the study, the aspect can vary from country level to firm or project level. At firm level, technological advantage represents a firm's ability to develop technology pushed breakthrough products instead of just satisfying existing demand (Samli \& Weber, 2000). At project (or product) level, technological advantage means the overall benefits of a product (compared to other similar products), which has been developed on the basis of technology.

Cooper and Kleinschmidt (1995) found that the success factors may be different at firm level and project level. There are many reasons for this, but, generalizing, there can be many different projects with different degrees of investment within the same firm. This principle applies to any success factor, including technological advantage. In this context we are primarily interested in technological advantages at project level and, secondarily, at firm level.

\section{Management related success factors}

\section{Management support}

Since management is too large a complex of issues to divide in this context, we share Ernst's (2002) view that the most important support from management is to ensure needed resources. Ernst also emphasizes that non- material support may be nothing more than lip-service. Samli and Weber (2000) explain that management must have adequate financial and human resources for generating breakthrough products.

\section{Degree of funding}

The degree of funding is an important part of a firm's NPD strategy. In a study of Samli and Weber (2000), a generous majority of researched firms spent more than 20 per cent of their total budgets on developing new products, and this fact was the most important consideration. In general, adequate funding (and personnel) must be available, and it must be maintained during the development process for carrying out the research and development process (Samli \& Weber, 2000).

Ulrich and Eppinger (2008) suggest that aggregate planning for firms in terms of efficient use of their resources is pursuing only projects which can reasonably completed with budgeted resources. In a planning phase, management must prioritize the most important projects in terms of the success of the firm, those projects that are realizable with adequate resources. Other projects can be stopped or postponed.

\section{Organization related success factors}

\section{Project team skills}

Sarja (2015) found a few characteristics of development personnel: training, experience, commitment, expertise, motivation and ability. The author summarized these characteristics as team skills. In this study, we do not consider skills at the individual level; we focus on the thought that team skills are the consequence of cross-functional teams. Actually, this was the original idea of teams (e.g. Marquis \& Straight, 1965). In general, many cross-functional team related studies emphasize the relationships between marketing and R\&D (e.g., Griffin \& Hauser, 1996). Crossfunctionality has been found, without exception, to be a success factor of NPD (e.g., Cooper \& Kleinschmidt, 1995). We share our focus with Ulrich and Eppinger (2008); a product development team should have expertise at least in marketing, design and manufacturing functions.

\section{Networking}

The way to consolidate in-house know how and resources is networking. The first phase of the networking concept includes lead users or customers in the development process (e.g., von Hippel, 1988; Kristensson et al., 2004). Bishop and Magleby (2004 in Sarja, 2015) required (but not described) more; networking must be beyond interacting 
with customers and end users. The next logical step is supplier involvement (e.g., Ragatz et al., 2002). Freel (2003) explored the relationship between networking with three horizontal actors: competitors, universities and the public sector. Aside from consolidating in-house know how, the benefits of networking are also risk and cost sharing, access to new technologies and markets and attempts to shorten development time (Ledwith \& Coughlan, 2005).

While networking was recognized as one of the key factors of technology pushed products, Ledwith and Coughlan (2005) found that there are conflicting findings in several studies between networking on a new product development and increased success. Their own study of 60 electronics firms found the same results. Therefore, the authors suggested a framework for managing networking in NPD projects for reaching successful collaboration. The framework is based on three variables:

I) The type of organization with which to collaborate Who? Which organizations should firms involve in their NPD projects?

2) The skills or absorptive capacity of a firm

Skills? Do the firms have the necessary skills to benefit from the collaboration?

3) A firm's new product strategy

Why? Are the reasons for collaboration consistent with the firms NPD strategy?

\section{The survey instrument framework}

The research push case study survey instrument framework is based on the introduced success factors. The framework is illustrated in figure 5. The proposed framework is relatively broad and it is possible to use only part of it depending on the focus of the case study. The framework is meant to be used in various types of data collection in case studies, for example interviews, surveys, document and literature analyses and so on.
The framework does not offer detailed questions, but the researchers can lead the questionnaires or make interview questions accordingly, depending on the method used.

The framework leads to a focus to marketing related activities, organizational abilities and resource and time aspects, and these determinants are discussed below.

\section{MARKET RELATED SUCCESS} FACTORS

MP methods used

Focus on customer needs

Market development

Alternative study

Adoption time and technophobia

\section{PRODUCT RELATED SUCCESS} FACTORS

TP for difficult adopted

Life cycle

Fill an unrecognized need

Technological advantages

MANAGEMENT RELATED SUCCESS FACTORS

Management support

Degree of funding

ORGANIZATION RELATED SUCCESS FACTORS

Project team skills

Networking

Figure 5. The survey instrument framework 


\section{Discussion}

The aim of the transcription of TP success factors is to help a firm's management to recognize the real actions needed to reduce product development risks and to help scholars to focus on the right issues when studying the key factors of breakthrough cases. For example, different survey instruments (e.g., questionnaires, surveys) can be built accordingly.

After defining the content of TP success factors, we found three keynotes, which combine the definitions.

The first keynote in the study is market observation activities in parallel with product development, or, rather, embedding them as a part of the development process. This can be seen from different angles in terms of several success factors. MP methods used guides the start of market observation immediately when planning a new product idea. This success factor also emphasizes another important issue; the development process, including marketing activities, should be the same regardless of the innovation driver (TP or MP). Consequently, customer needs must be identified systematically (focus on customer needs, fill an unrecognized need), and alternative solutions in the market must be studied in terms of customer needs instead of in terms of just itemizing competitors (alternative study). The outgrowth of these studies is the target market (existing or new) definition (market development). Technological ability contributes to developing valuable new products for customers, filling recognized - and in the ideal case - also unrecognized needs (technological advantages).

The second keynote relates to organizational ability. The core task of a firm's management from the product development perspective is to ensure needed resources for development work (management support). Because resources are always limited, they must be allocated in terms of the results of aggregate planning and project prioritizing (degree of funding). Generally, resources consist of human and financial domains (Samli \& Weber, 2000). A capable development team is cross functional (project team skills), and the way to consolidate in-house know how and resources is networking (networking). Because of previous conflicting findings between NPD and increased success, networking activities must be planned strategically (Ledwith \& Coughlan, 2005).

The third keynote associates financial resources and different time aspects. As discussed, a long adoption time of TP products lies ahead. From a customer perspective, this means the acceptance time of new technology. At least partly, the acceptance time can be shortened by userfriendly design (adoption time, technophobia). From a firm's perspective, a long run commitment to a project is required, in the other words, adequate financing (TP for difficult adopted). Finally, if the project is well planned and it pulls through the development phase, the end of the life (and payback) time is expected to be longer (life cycle).

It is notable that an important factor in terms of product attributes is user-friendliness. There might be some other technological- or product-related attributes as well, but it seems that the current does not recognize them. Another notable thing is that, depending on research angle, a single success factor can be thematized differently.

The suggested success factors are based on the findings of two broad meta-analyses by Samli and Weber (2000) and Bishop and Magleby (2004) and are pre-analyzed by Sarja (2015). The novelty of this study is the explanatory definitions of the discussed key factors, and, in that sense, it confirms and refines previous studies. For further research, we propose to test suggested key factors in breakthrough case studies. Naturally, there is some space when applying the results of this study. If some success factors are in closer examination in a case study, it is possible to go deeper. For example, Peteraf and Bergen (2002; 2003) broadened the competitor analysis framework in comparison to Chen (1996).

\section{Conclusion}

The current literature does not introduce many firm success factors clearly. The factors may be presented too widely. In many cases, the factors were found to be self-evident, but, on closer examination, they may have different meanings. This can be a problem when researching the success factors of any business.

It is important to be aware of what the success factors exactly mean. It is valuable for a firm's management to recognize the real actions needed to reduce product development risks, and also helps scholars to focus on the right issues when studying the key factors of breakthrough cases.

Based on two TP specific meta-analyses, this paper presents proposed reasonings and definitions of success factors in the NPD domain. The survey instrument framework for TP research cases is also introduced. Implications are drawn for future research on testing TP success factors in TP project cases using the survey instruments from the introduced framework. 


\section{Acknowledgements}

I present my warmest thanks to Professor Samuli Saukkonen for the great guidance. I want also thank the Ahti Pekkala Foundation and the University of Oulu Scholarship for financial support for my research project.

\section{References}

BALACHANDRA, R. \& FRIAR, J. (1997). Factors for success in R\&D projects and new product innovation: $A$ contextual framework. IEEE Transactions on Engineering Management, 44(3), 276-287. doi: 10.1109/17.618169

BASS, F.M. (1969). A new product growth model for consumer durables. Management Science, 15 (January), 215227. doi: $10.1287 / \mathrm{mnsc}$. 15.5 .215

BERGEN,M.\& PETERAF,M.(2002).Competitor identification and competitor analysis:A broad-based managerial approach. Managerial and Decision Economics, 23, 157-169. doi: 10.1002/mde. 1059

BISHOP, G.L. \& MAGLEBY, S.P. (2004).A review of technology push product development models and processes. Proceedings of ASME DECT '04, ASME, New York, NY, 383392. doi: 10.1 II5/detc2004-57496

BROSNAN, M. (1998). Technophobia: The psychological impact of information technology. Routledge, NY.

CALANTONE, R. \& LI, T. (1998). The impact of market knowledge competence on new product advantage: conceptualization and empirical examination. Journal of Marketing, 62 (4), I3-29. doi: I0.2307//252284

CHEN, M. (1996). Competitor analysis and interfirm rivalry: toward a theoretical integration. Academy of Management Review, 2 I, I00-I34. doi: 10.2307/25863 I

CHRISTENSEN, C. (1997). The innovator's dilemma: when new technologies cause great firms to fail. Boston: Harvard Business School Press.

COOPER, R.\& KLEINSCHMIDT,E. (1995). Benchmarking the firm's critical success factors in new product development. The Journal of Product Innovation Management, 12 (5), 37439 I. doi: I0.1 I I I/I540-5885.1250374

DAVIS, F. (1989). Perceived usefulness, perceived ease of use, and user acceptance of information technology. MIS Quarterly, I3(3), 319-340. doi: 10.2307/249008
ERNST, H. (2002). Success factors of new product development: a review of the empirical literature. International Journal of Management Reviews, 4(I), I-40. doi: |0.1 II I/|468-2370.00075

FREEL, M. (2003). Sectoral patterns of small firm innovation, networking and proximity. Research Policy, 32, 75I-770. doi: 10.1016/s0048-7333(02)00084-7

FREEMAN, C. (1982). Schumpeter or Schmookler?. In C. Freeman, J. Clark \& L. Soete (Eds.), Unemployment and Technical Innovation. London: Pinter.

GREEN, S., GAVIN, M. \& AIMAN-SMITH L. (1995) Assessing a multidimensional measure of radical technological innovation. IEEE Transactions on Engineering Management, 42(3), 203-2 I4. doi: 10.I 109/17.403738

GRIFFIN, A. \& HAUSER, J. (1996). Integrating R\&D and Marketing: A review and analysis of the literature. Journal of Product Innovation Management, 13 (3), 191-215. doi: |0.1 I I I/I540-5885.|330|9|

HERSTATT, C. \& LETTL, C. (2004). Management of 'technology push' development projects. International Journal of Technology Management, 27(2-3), 155-175. doi: 10.1504/ijtm.2004.003950

ISAACSON,W. (20II). Steve Jobs. Otava: Keuruu.

JAY, T. (198I). Computerphobia. What to do about it. Educational Technology, 2I, 47-48.

KOTLER, P. \& ARMSTRONG, G. (1987). Marketing - An Introduction. Prentice-Hall, NJ.

KRISTENSSON, P., GUSTAFSSON, A. \& ARCHER, T. (2004). Harnessing the creative potential among users. Journal of Product Innovation Management, 2I, 4-14. doi: 10.1 III/j.0737-6782.2004.00050.x

LEDWITH, A. \& COUGHLAN, P. (2005). Splendid isolation: Does networking really increase new product success? Creativity and Innovation Management, 14 (4), 366-373. doi: I0.1 I I I/j. I 467-869I.2005.00356.x

LEWITT, T. (1960). Marketing myopia. Harvard Business Review, 38(4), 45-56.

MAHAJAN,V., MULLER, E. \& BASS, F.M. (1990). New product diffusion models in marketing: $A$ review and directions for research. Journal of Marketing, 54 (January), I-26. doi: $10.2307 / 1252170$ 
MAHAJAN,V.\&WIND,Y.(1986). Innovation diffusion models of new product acceptance. Cambridge, MA: Ballinger Publishing Company.

MARQUIS, D. \& STRAIGHT, D. (1965). Organizational factors in project performance. Cambridge, MA: MIT Sloan School of Management Working Paper.

McDERMOTT, C. \& O'CONNOR, G. (2002). Managing radical innovation:An overview of emergent strategy issues. The Journal of Product Innovation Management, 19(6), 424438. doi: 10.1 I I I/I540-5885.1960424

MUNRO, H. \& NOORI, H. (1988). Measuring commitment to new manufacturing technology: Integrating technological push and marketing pull concepts. IEEE Transactions on Engineering Management, 35(2), 63-70. doi: I0.I I09/I7.6006

NARAYANAN, S. (1992). Incorporating heterogeneous adoption rates in new product diffusion: $A$ model and empirical investigations. Marketing Letters, 3(4), 395-406. doi: I0.1007/bf00993923

PETERAF,M.\& BERGEN,M.(2002). Competitor identification and competitor analysis: a broad-based managerial approach. Managerial and decision economics. 23(4-5), 157-169. doi: 10.1002/mde. 1059

PETERAF, M. \& BERGEN, M. (2003). Scanning dynamic competitive landscapes:A market-based and resource-based framework. Strategic Management Journal, 24, I027-I04I. doi: $10.1002 /$ smj.325

RAGATZ, G., HANDFIELD, R. \& PETERSON, K. (2002). Benefits associated with supplier integration into new product development under conditions of technology uncertainty. Journal of Business Research, 55, 389-400. doi: I0.1016/s0148-2963(00)00I58-2

ROGERS, E. (1962). Diffusion of innovations. Free Press, NY.

ROSEN, L. \& WEIL, M. (1990). Computers, classroom instruction and the computerphobic university student. Collegiate Microcomputer, 8(4), 257-283.

SAMLI, A.C. \& WEBER, J.A.E. (2000). A theory of successful product breakthrough management: Learning from success. Journal of Product \& Brand Management, 9(I), 35-55. doi: 10.1108/10610420010316320

SARJA, J. (20I2). A review of the Getting Real software development approach. Int. J. Agile and Extreme Software Development, I(I), 78-94. doi: I0.I504/ijaesd.20I2.04830 I
SARJA, J. (2015, in press). Key factors of successful technology push projects in the ICT context:A review of the literature. International Journal of Information Technology and Management.

SOUDER, W. E. (1989). Improving productivity through technology push. Research Technology Management, 32(2), |9-3I. doi: I0.1016/0737-6782(89)90092-I

SULTAN, F., FARLEY, J. \& LEHMANN, D. (1990). A metaanalysis of diffusion models. Journal of Marketing Research, 22 (February), 70-77. doi: 10.2307/3। 72552

TSENG, H. \& CHEN,W. (2004).A replacement consideration for the end-of-life product in the green life cycle environment. Int. J. of Advanced Manufacturing Technology, 24(II-I2), 925931. doi: 10.1007/s00170-003-1809-5

ULRICH, K.T. \& EPPINGER, S.D. (2008). Product Design and Development. Irwin/McGraw-Hill.

VENKATESH, V. \& BALA, H. (2008). Technology acceptance model 3 and a research agenda on interventions. Decision Sciences, 39(2), 273-3I5. doi: 10.1III/j.15405915.2008.00192.x

VENKATESH,V. \& DAVIS, F. (2000). A theoretical extension of the technology acceptance model: four longitudinal field studies. Management Science, 46(2), I86-204. doi: 10.1287/ mnsc.46.2.186.11926

VENKATESH,V., MORRIS, M., DAVIS, G. \& DAVIS, F. (2003). User acceptance of information technology: toward a unified view. MIS Quarterly, 27(3), 425-478.

VON HIPPEL, E. (1988). The Sources of Innovation. Oxford University Press: Oxford

ZMUD, R.W. (1984). An Examination of "Push-Pull" Theory Applied to Process Innovation in Knowledge Work. Management Science, 30(6), 727-738. doi: 10.1287/ mnsc.30.6.727 